has a total of between 200,000 and 400,000 alcoholics, and that the death rate from alcoholism has for the last 20 years been rising.

Given the committee's knowledge of a threatening public health situation, what did it envisage as the likely impact on health of its proposals? It says that the health consequences need watching and suggests that there should be continued research monitoring, but it goes on to conclude that the recommendations as a whole will probably not have any adverse effect on health. In an important passage (p. 46) the committee makes an assertion which shows something of its approach to these questions: it states that at one extreme total permissiveness would have a large adverse effect on health, while at the other extreme unacceptable repressive policies would have considerable impact of a contrary sort. Then it makes this key assertion, "Any solution which fell well within these limits would, we feel, be largely neutral in its impact on consumption."

The impression is given that the committee is set on policies of relaxation for reasons other than those concerning the public health. From the public health point of view the report's main proposals must be condemned as untimely. Their adoption in practice would be to risk a further increase in alcoholism, with its attendant dangers to harmony in the home and life on the roads.

1 Report of the Departmental Committee on Liquor Licensing. London, H.M.S.O., 1972.

2 Lederman, S., Alcool-Alcoolism-Alcoolisation : Donées Scientifiques de caractère et physiologique, économique et sociale. Paris, Presse Universitaires de France, 1956.

\section{Retinal Veins in Multiple Sclerosis}

The eyes, those windows on the soul, may often given an indication of an underlying general or neurological disease. ${ }^{1-5}$ Multiple sclerosis presents with optic neuritis in $10-20 \%$ of patients and with some ocular symptoms in about $30 \%$ of patients. ${ }^{6-8}$

One ocular feature of multiple sclerosis which has caused interest and discussion over the years is the sheathing of the retinal veins first described by Wilbur Rucker in 1944.910 He has recently reviewed his own and others' experience of this condition. ${ }^{11}$ Sheathing is seen as a fine, opaque border to the veins of the retina, and is thought to be of significance in relation to multiple sclerosis only if it occurs at a distance from the optic nerve head. Many conditions such as papillitis and papilloedema may cause sheathing of the veins at the nerve head. Other changes also included within the term of "sheathing" are soft, opaque clouds in the vitreous over the veins, which may be more acute phenomena. The parallel sheathing of veins may be due to slight thickening and increased visibility of the vein walls, and may remain for many years.

These changes are seen only with difficulty, and require that the pupil be fully dilated and the ophthalmoscope light not too bright. Though more than 500 cases have now been reported, other workers have failed to find evidence of retinal-vein sheathing despite diligent search. ${ }^{12} 13$

The sheathing of the retinal veins never causes symptoms, and is therefore of little importance in itself. But it may on occasions be of help in suggesting a diagnosis of multiple sclerosis, though few would rely on it, parti- cularly now that more modern diagnostic techniques are available, including the raised level of gammaglobulin in the cerebrospinal fluid. ${ }^{14}$ It might reasonably be questioned whether the sheathing could have any aetiological significance in relation to multiple sclerosis, since the nerves in the retina are not myelinated. However, the presence of an abnormality of the veins gives some support to the longstanding suggestion that plaques of multiple sclerosis have their origin in the first place round veins in the central nervous system ${ }^{1516}$ No relationship to the pathological changes has yet been found in the veins showing sheathing in life. T. Fog ${ }^{16}$ illustrated inflammatory cell infiltration of a retinal vein in an eye removed from a patient, though unfortunately there was no observation of retinal sheathing during life.

1 Pattison, E. M., Archives of Neurology, 1965, 12, 197. 2 Daroff, J., and Waldman, A. L., Fournal of Neurology, Neurosurgery and

8 Fisher, C. M., Fournal of Neurology, Neurosurgery and Psychiatry, 1967, $30,383$.

4 Crews, S. J., Hospital Medicine, 1967, 2, 543.

5 Harcourt, R. B., British fournal of Hospital Medicine, 1969, 2, 831

- Holden, W. A., in Multiple Sclerosis. Association for Research in Nervous

and Mental Diseases, 1921, 2, 102 . A Reappraisal. London, Livingstone, 1965.

A Reappraisal. London, Livingstone, 1965.

' Leibowitz, U., and Alter, M., Acta Neurologica Scandina

10 Rucker, C. W., Association for Research in Nervous and Mental Disease, $1950,28,396$.

11 Rucker, C. W., Mayo Clinic Proceedings, 1972, 47, 335.

12 Field, E. J., and Foster, J. B., fournal of Neurology, Neurosurgery and Psychiatry, 1962, 25, 269.

13 Lössner, J., Müller, J., and Bachmann, H., Ophthalmic Literature, 1968, 22, 734.

14 Prineas, J., Teasdale, G., Latner, A. L., and Miller, H., British Medical Fournal, 1966, 2, 922.

15 Putman, T. J., and Adler, A., Archives of Neurology and Psychiatry, 1937,

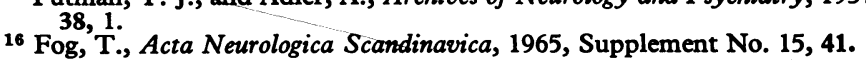

\section{Transmission of Cholera}

The recent outbreak of cholera among passengers on an airliner travelling from Great Britain to Australia was confirmed as due to the el tor vibrio. The Australian authorities were quickly led to suspect the smörgåsbord that was taken on board for economy class passengers at Bahrain as the vehicle of infection. The water from the aircraft was shown to be perfectly satisfactory. Only economy class passengers were affected; none of the crew and first-class passengers had the smörgåsbord. The recognition of two other cases among passengers on a flight in the opposite direction, which had also taken on smörgåsbord about the same time, helped to confirm this. All the evidence was that this was a food-borne outbreak. Thus cholera, traditionally considered to be the classic example of a water-borne disease, was presenting as a food-borne infection. Many questions may be asked about the method of spread of el tor cholera and the significance of the cholera carrier today.

It is certainly true that countries where sewage disposal is inadequate and where a clean water supply is lacking may suffer from water-borne outbreaks. In many areas of the world water is drawn for drinking and cooking from the very rivers and ponds into which defecation takes place. But in the present pandemic of el tor cholera there has been much evidence of case-to-case spread. In the Phillippines ${ }^{1}$ the infecton was found to be transmitted from person to person until a water supply was contaminated, as a result of which an explosive outbreak occurred. An explosive outbreak in Istanbul was rapidly brought under control by the 